\title{
Photonic modulation of epidermal growth factor receptor halts receptor activation and cancer cell migration
}

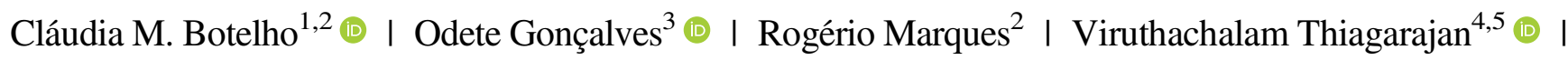 \\ Henrik Vorum ${ }^{6}$ (1) I Andreia C. Gomes ${ }^{2,3 *}$ (1) । Maria Teresa Neves-Petersen ${ }^{3,4,6 *}$ (1)
}

${ }^{1}$ Centre of Biological Engineering, Universidade do Minho, Braga, Portugal

${ }^{2}$ Centre of Molecular and Environmental Biology (CBMA), Universidade do Minho, Braga, Portugal

${ }^{3}$ Department of Health Science and Technology, Aalborg University, Aalborg, Denmark

${ }^{4}$ International Iberian Nanotechnology Laboratory (INL), P-4715-310 Braga, Portugal

${ }^{5}$ School of Chemistry, Bharathidasan University, Tiruchirappalli, India

${ }^{6}$ Department of Clinical Medicine, Aalborg University Hospital, Aalborg, Denmark

\section{*Correspondence}

Andreia Castro Gomes, Centre of Molecular and Environmental Biology (CBMA), Universidade do Minho, 4710-057 Braga, Portugal.

Email: agomes@bio.uminho.pt

Maria T. Neves-Petersen, International Iberian Nanotechnology Laboratory (INL), P-4715-310

Braga, Portugal.

Email: nevespetersen@gmail.com; tneves@dcm. aau.dk

Funding information

Fundação para a Ciência e a Tecnologia, Grant/ Award Numbers: SFRH/BPD/111291/2015, SFRH/BSAB/ 127924/2016, POCI-

01-0145-FEDER-007569, UID/BIO/04469/2013, COMPETE 2020 (POCI-01-0145-FEDER006684), RECI/BBB-EBI/0179/2012 (FCOMP01-0124-FEDER-027462)

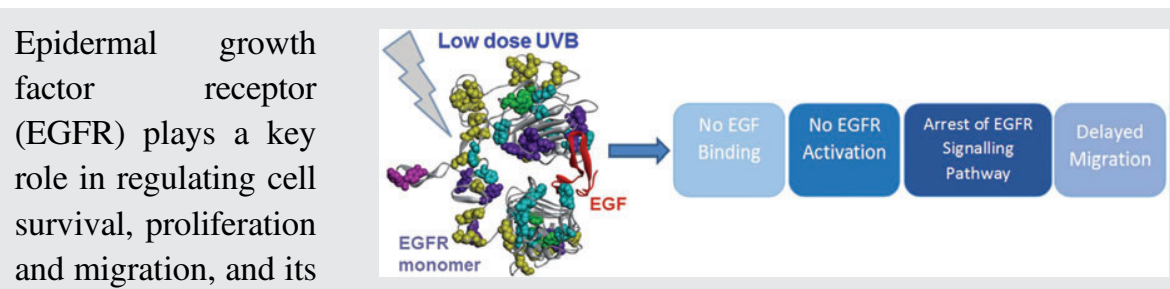
overexpression and activation has been correlated with cancer progression. Cancer therapies targeting EGFR have been applied in the clinic with some success. We show, by confocal microscopy analysis, that illumination of adenocarcinomic human alveolar basal epithelial cells (Human A549-EGFR biosensor cell line) with $280 \mathrm{~nm}$ at irradiance levels up to 20 times weaker than the Ultraviolet B (UVB) solar output for short periods of time (15-45 minutes) prevents epidermal growth factor-mediated activation of EGFR located on the cell membrane, preventing or reducing cellular disaggregation, formation of filopodia and cell migration. This effect of Ultraviolet (UV) light illumination was confirmed further in a functional scratch assay, and shown to be more effective than that of a specific EGFR-signaling inhibitor. This new photonic approach may be applicable to the treatment of various types of cancer, alone or in combination with other therapies.

\section{KEYWORDS}

arrest cancer cell migration, EGF, EGFR, metastasis, photonic cancer therapy, protein photochemistry

\section{1 | INTRODUCTION}

Many current cancer therapies aim at inhibiting the epidermal growth factor receptor (EGFR). EGFR is a membrane receptor that plays a key role in regulating cell survival and proliferation [1-5], being a member of the ErbB family of receptor tyrosine kinases (RTKs) [6]. EGFR binds to ligands, such as epidermal growth factor (EGF) leading to receptor dimerization and activation of the tyrosine kinase domain [7-9]. This leads to downstream activation of signal transduction cascades, mainly the mitogen-activated protein kinase (MAPK), AKT (or Protein Kinase B) and c-Jun N-terminal kinase (JNK) pathways $[10,11]$. These pathways modulate cell migration, adhesion and proliferation.

High expression of EGFR is generally associated with cancer progression, invasion, metastasis, late-stage disease, chemotherapy resistance, hormonal therapy resistance and poor general therapeutic outcome [8, 12-15]. Typical chemotherapeutical agents are tyrosine kinase inhibitors that compete with Adenosine triphosphate (ATP) at the intracellular tyrosine kinase domain $[6,9,12]$ and monoclonal 
antibodies $[6,9,13]$ that prevent ligand-binding or receptor dimerization. Blocking EGF binding to EGFR can abolish cancer proliferation, invasion, metastasis, angiogenesis and inhibition of apoptosis. It is known that the structure of EGFR can be altered and rendered inactive by $280 \mathrm{~nm}$ light, impairing the correct binding of ligands [16, 17]. Furthermore, $280 \mathrm{~nm}$ irradiation leads to the arrest of EGFRdependent key signaling pathways [14].

In the present study, we show that illumination of lung carcinoma cells with low dose UVB $\left(0.09-0.27 \mathrm{~W} / \mathrm{m}^{2}\right.$ at $280 \mathrm{~nm}$ ) inhibits EGF-mediated activation of EGFR. Importantly, we screened for the effect of irradiation on the formation of filopodia and on cellular migration promoted by EGFR activation. These irradiance values, applied for short periods of time (15-45 minutes), are up to 20 times weaker than the UVB levels in the solar output. The effect of UV irradiation on cellular migration was also compared to the effect of tyrphostin AG1478, a specific EGFR-signaling inhibitor [18]. Our goal is to develop a new photonic therapy that reduces uncontrolled migration of cancer cells as well as their invasiveness. Taking this technique from the bench to the clinical practice would be straightforward, when compared to other photonic based techniques, as little secondary or deleterious effects are foreseen when using such low power light.

\section{2 | MATERIALS AND METHODS}

\section{1 | Cell line}

The main cell line used in this study was the A549-green fluorescent protein (GFP)-tagged $\mathrm{SH} 2$ biosensor cell line (Sigma-Aldrich, Saint Louis, Missouri, CLL1141) [19]. The SH2 domain protein, fused to GFP, has high affinity for RTKs, acting as a biosensor of endogenous EGFR activity. Upon ligand binding, activation of RTKs and consequent phosphorylation of tyrosine residues leads to recruitment of the chimeric SH2 domain-based biosensor, followed by receptor endocytosis and recycling. EGFR function in live cells may then be evaluated by the formation of green granules [20-22].

The cells were kept at $37^{\circ} \mathrm{C}$ in a $5 \% \mathrm{CO}_{2}$ atmosphere. Cells were cultured in Dulbecco's Modified Eagle Medium (DMEM) with $2 \mathrm{mM}$ glutamine, $1 \mu \mathrm{g} / \mathrm{mL}$ puromycin (complete medium) and $10 \%$ of fetal bovine serum (FBS). The parental cell line A549 (human lung carcinoma) was used in the proliferation assay as a control. All reagents were purchased from Sigma-Aldrich except otherwise stated.

\section{2 | Proliferation assay}

Cell proliferation was determined by 2 methods, Sulforhodamine B (SRB) and Resazurin. For the SRB, A549-GFP cells were seeded in 96 well plates $\left(10^{5}\right.$ cells $\left./ \mathrm{mL}\right)$ and incubated overnight at $37^{\circ} \mathrm{C}$ in $5 \% \mathrm{CO}_{2}$ atmosphere. The culture medium was replaced by DMEM containing $2 \%$ of FBS and EGF (0.1-2 nM). After 24 hours, the cells were washed with PBS and fixed with $1 \%$ acetic acid in $100 \%$ methanol solution. About $0.5 \%$ of SRB (in $1 \%$ acetic acid) was added to each well and incubated at $37^{\circ} \mathrm{C}$ for 1 hour, followed by 3 washes with $1 \%$ acetic acid solution. SRB was dissolved with $10 \mathrm{mM}$ Tris solution and absorbance read at $540 \mathrm{~nm}$.

For the Resazurin assay, cells (A549 and A549-GFP) were seeded in 24 well plates $\left(2.2 \times 10^{4}\right.$ cells $\left./ \mathrm{mL}\right)$ and incubated overnight at $37^{\circ} \mathrm{C}$ in $5 \% \mathrm{CO}_{2}$ atmosphere. The culture medium was replaced by DMEM containing $2 \%$ of FBS and EGF (0-32 nM). Then, 8 hours after the first EGF stimulus, the cells were incubated for 2 hours with Resazurin and the respective absorbance measured at $600 \mathrm{~nm}$. Fresh culture medium with EGF was added to cells and incubated for an additional 8 hours. This protocol was repeated to evaluate cell proliferation.

We proceeded to determine if $280 \mathrm{~nm}$ illumination changes the proliferation of A549 GFP cells stimulated with $2 \mathrm{nM}$ EGF. The cells were seeded in 24 well plates $\left(2.2 \times 10^{4}\right.$ cells $\left./ \mathrm{mL}\right)$ and incubated overnight at $37^{\circ} \mathrm{C}$ in $5 \%$ $\mathrm{CO}_{2}$ atmosphere. The cells were irradiated at a wavelength of $280 \mathrm{~nm}$ with an irradiance of $0.27 \mathrm{~W} / \mathrm{m}^{2}$ for 30 minutes. After this period, the culture medium was replaced by DMEM containing $2 \%$ FBS and 2 nM EGF. Then, 8 hours after the first EGF stimulus, the Resazurin assay was performed as described. At this point, fresh culture medium with 2 nM EGF was added to the cell culture and after an incubation of 8 hours, the Resazurin assay was repeated. The statistical analysis was performed using the Statistical Package for the Social Sciences.

\section{3 | Migration assay}

A549-GFP cells were seeded into 12 well plates $\left(2.2 \times 10^{4}\right.$ cells $\left./ \mathrm{mL}\right)$ and incubated overnight at $37^{\circ} \mathrm{C}$ in $5 \% \mathrm{CO}_{2}$ atmosphere. A scratch was performed disrupting the confluent cell monolayer. In order to assess the influence of the UV light $(280 \mathrm{~nm})$ on cell migration, the cells were irradiated at $280 \mathrm{~nm}$ (LED) with an irradiance of $0.27 \mathrm{~W} / \mathrm{m}^{2}$ for 30 minutes. The culture medium was replaced by DMEM containing $2 \%$ of FBS, EGF ( 0 or $2 \mathrm{nM}$ ). Where appropriate, $1 \mu \mathrm{M}$ Thyrphostin AG1478 (Thyr), a specific EGFR signaling tyrosine kinase inhibitor shown to be effective in A549 cells [19], was added. Cell migration was followed by phase contrast microscopy for a period of 20 hours, sufficient for scratch closure. Three micrographs of each experimental condition were taken at every timepoint with the $\times 10$ objective. The area devoid of cells at 0 and 20 hours was calculated in pixels using the MRI Wound Healing Tool macro for open-software platform ImageJ and the percentage of reduction in scratch area between the first and last timepoints was calculated. The values in wound area variation were calculated and 
indicated in Figure 4 (mean of 3 different images of the same experiment $\pm \mathrm{SD})$.

\subsection{UVB $(280 \mathrm{~nm})$ illumination setup}

\subsection{1 | Illumination prior to Confocal Laser Scanning Microscopy}

Illumination at $280 \mathrm{~nm}$ was provided by the Xe arc lamp (LX 300UV) of an ISS Chronos BH steady-state fluorometer with a computer controlled monochromator. The light was focused onto an optical fiber with a core diameter of $150 \mu \mathrm{m}$. Light intensity was adjusted by regulating the lamp current between 10 and $18 \mathrm{~A}$ and by adjusting the monochromator slit width from 8 to $16 \mathrm{~nm}$. Light was shaped to a 1-cm-diameter circular beam and passed centrally through the excitation volume. The cells were illuminated for 15 and 30 minutes with $280 \mathrm{~nm}$ light at $0.27 \mathrm{~W} / \mathrm{m}^{2}(0.021 \mathrm{~mW}$, $10 \mathrm{~A}$, slit width $16 \mathrm{~nm})$ and $0.09 \mathrm{~W} / \mathrm{m}^{2}(0.007 \mathrm{~mW}, 10 \mathrm{~A}$, slit widths $8 \mathrm{~nm}$ ). An additional experiment was carried out illuminating the cells with $280 \mathrm{~nm}$ light at an irradiance of $1.18 \mathrm{~W} / \mathrm{m}^{2}(0.093 \mathrm{~mW}, 18 \mathrm{~A}$, slit width $16 \mathrm{~nm})$ for 15 and 45 minutes. The temperature of the sample was kept at room temperature $\left(\sim 22^{\circ} \mathrm{C}\right)$ during illumination. The irradiance levels used $\left(0.09,0.27\right.$ and $\left.1.18 \mathrm{~W} / \mathrm{m}^{2}\right)$ were chosen based on data previously published by our group and based on the irradiance levels in the UVB domain emitted by the sun. Correia et al. [16] demonstrated that irradiation of EGFR with UVB light $(280 \mathrm{~nm})$ at an irradiance level of $0.08 \mathrm{~W} /$ $\mathrm{m}^{2}$ induced structural changes in the receptor. Furthermore, Olsen et al. [14] demonstrated that the irradiation of 2 cell lines overexpressing EGFR, A431 (human epidermoid carcinoma cells) and Cal39 (derived from human vulva squamous cell carcinoma cells), with an irradiance of $0.35 \mathrm{~W} / \mathrm{m}^{2}$, blocks the EGFR signaling pathway. The chosen irradiance levels are up to 22 times weaker than the UVB solar output. The sunlight irradiance of the UVB region is reported to be $1.75 \mathrm{~W} / \mathrm{m}^{2}$ at $39^{\circ}[15]$.

\subsection{2 | Illumination prior to the Migration assay}

The cells were illuminated with a high power Fiber-Coupled $280 \mathrm{~nm}$ LED Light Source controlled by a 2-channel LED driver with manual and analog-input controls. The high power Fiber-Coupled $280 \mathrm{~nm}$ LED Light Source (product number FCS-0280-000), Multimode Fiber Patchcord, 0.22 NA, $600 \mu \mathrm{m}$ with Core subminiature assembly (SMA) Connectors (product number FPC-0600-22-02SMA) and the 2-channel LED driver with manual and analog-input controls, maximum current $100 \mathrm{~mA}$ (product number SLA0100-2) were purchased from Azpect (AZPECT PHOTONICS AB, Mölndal, Sweden).

\section{5 | Confocal Laser Scanning Microscopy}

The morphology and the mobility of non-illuminated vs $280 \mathrm{~nm}$ illuminated cells were monitored using confocal laser scanning microscopy (CLSM). All the experiments were carried out at $37^{\circ} \mathrm{C}$ using a heat chamber coupled onto the Zeiss-LSM780. The cell medium containing 2\% FBS was supplemented with $2 \mathrm{nM}$ EGF. The addition of EGF was considered the time zero for the time-lapse experiments.

To determine if the laser line at $488 \mathrm{~nm}$ used to image the green fluorescence of A549-GFP cells in the CLSM influenced the observed results, the cells were irradiated for 30 minutes at $488 \mathrm{~nm}$ with an irradiance of $0.27 \mathrm{~W} / \mathrm{m}^{2}$. Cells were then imaged every 2 minutes up to 60 minutes and imaged only twice, first at time zero and at 60 minutes after being kept in the dark. Nonirradiated cells were kept under the same conditions and imaged as a control.

\subsection{Statistical analysis}

Data from SRB and Resazurin proliferation assays were analyzed using ANOVA test with Bonferroni as a post hoc test, with a significance level defined at $P<.05$.

\section{3 | RESULTS}

\section{1 | A549-GFP cells are a good model to evaluate effect of light on EGF-mediated activation}

To validate the experimental model and settings used throughout the study, several control experiments were performed. The cell line used, A549-GFP-tagged SH2 biosensor cell line, expresses a fluorescent chimeric fusion protein: an EGFR protein tagged with GFP. EGF-mediated activation leads to redistribution of EGFR (and, thus, of GFP) from the cell membrane to endosomes.

These cells were irradiated with $280 \mathrm{~nm}$ light ranging between 0.09 and $1.18 \mathrm{~W} / \mathrm{m}^{2}$. The highest irradiation level $\left(1.18 \mathrm{~W} / \mathrm{m}^{2}\right) \mathrm{did}$ not induce EGFR activation, fluorescence bleaching or morphological changes of the cancer cells. The putative bleaching effect (not observed) would be even lower in the experiments using a lower irradiance, as done in the present study. Similarly, the exposure to the wavelength of $488 \mathrm{~nm}$ in the CLSM did not induce any morphological changes to the confluent cell monolayer or activated the EGFR, irrespectively to exposure time (every 2 minutes for 60 minutes or twice in 60 minutes). The same was observed with the control cells kept in the dark during these 60 minutes.

The proliferation rate of A549-GFP cells tends to be highest when the cells are stimulated with 2 nM EGF (Figure 1, SRB method). However, although consistent, the differences observed are not statistically significant $(P>.05)$. Different EGF concentrations were screened to identify $2 \mathrm{nM}$ as the optimal concentration to stimulate proliferation in A549-GFP-tagged SH2 biosensor cells. Figure S1(A), Supporting Information shows that, although there is consistently a natural increase in cell proliferation 


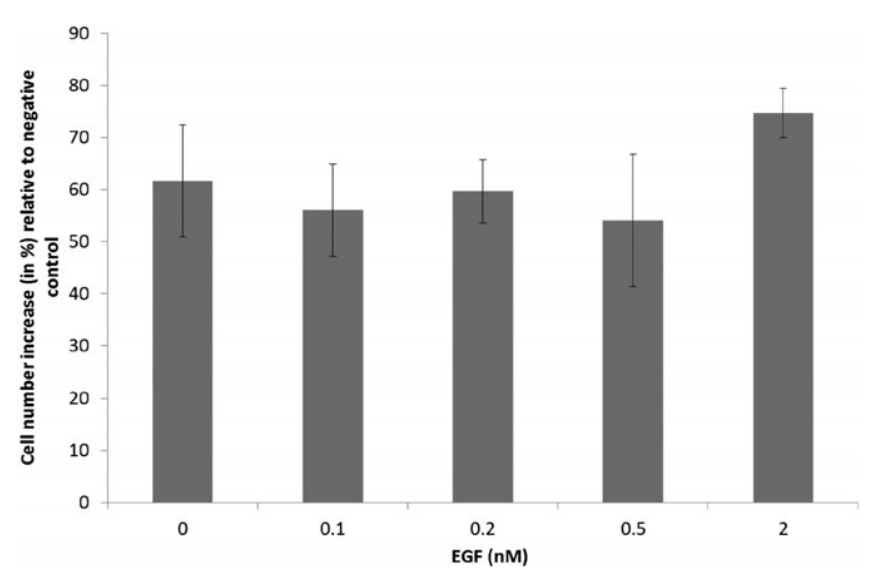

FIGURE 1 Cell number increase (in \%) relative to the negative control (negative control: buffer $10 \mathrm{mM}$ acetic acid was used instead of growth medium, no EGF present) of A549-GFP cells cultured in the presence of different concentrations of EGF

(measured by SRB assay) from 8 to 24 hours in the presence of 2 nM EGF, such increase is not paramount. Figure S1 (B) illustrates an experiment where we followed the proliferation of these cells stimulated with 2 nM EGF over 4 days; it shows that after a peak at day 1 , the cells tend to invert growth even with continuous EGF stimulation; this was observed by us in other experiments not shown here. Figure S1(C) shows yet another independent experiment (3-(4,5-Dimethylthiazol-2-yl)-2,5-diphenyltetrazolium bromide (MTT) assay) where it is clarified that it is important to remove or reduce bovine serum in the culture medium to evaluate proliferation of A549-EGFR biosensor cells at 24 hours in the presence of $2 \mathrm{nM}$ EGF.

An additional proliferation experiment was performed with Resazurin to compare A549-GFP cells and the parental cell line (A549) (Figure 2). Both cell lines were stimulated with EGF at 2 different time points. Data show a similar

(A)

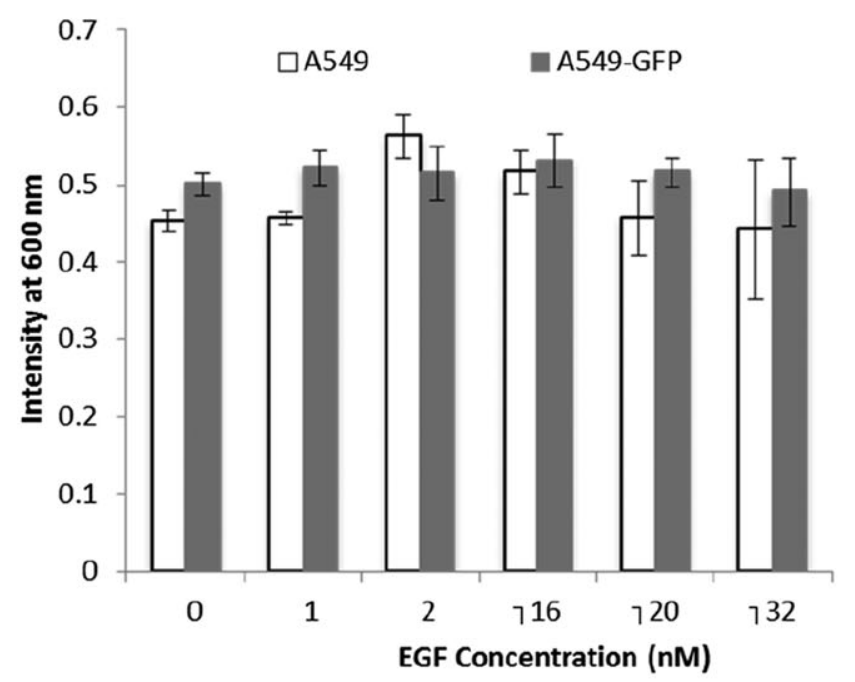

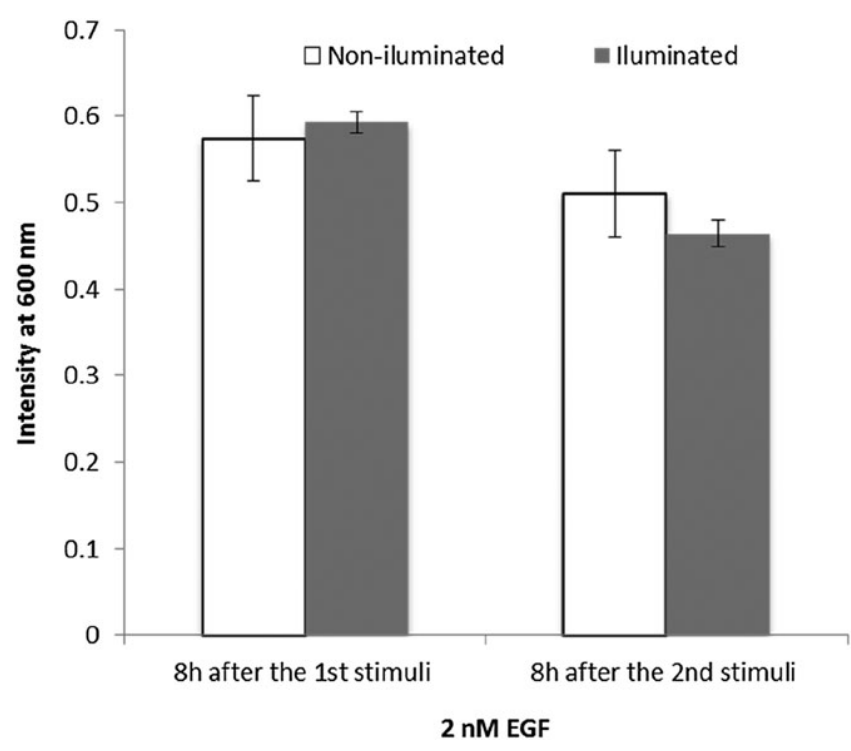

FIGURE 3 Absorbance Intensity measured at $600 \mathrm{~nm}$ for A549-GFP cells stimulated with $2 \mathrm{nM}$ of EGF and irradiated with $0.27 \mathrm{~W} / \mathrm{m}^{2}$ for 30 minutes. Data were acquired 8 hours after the first EGF stimulus and 8 hours after the second EGF stimulus

behavior in parental A549 cells and in the reporter cell line A549-GFP. No statistically significant differences were detected in the proliferation of A549 when compared the A549-GFP cells stimulated with different EGF concentrations $(P>.05)$.

\section{2 | UV illumination does not affect cell proliferation but influences motility of A549-GFP cells}

To determine if $280 \mathrm{~nm}$ illumination directly affects EGFinduced proliferation of A549-GFP cells, these were irradiated prior to stimulation with $2 \mathrm{nM}$ EGF every 8 hours to maintain EGF bioavailable (Figure 3). Figure S1(C) shows

(B)

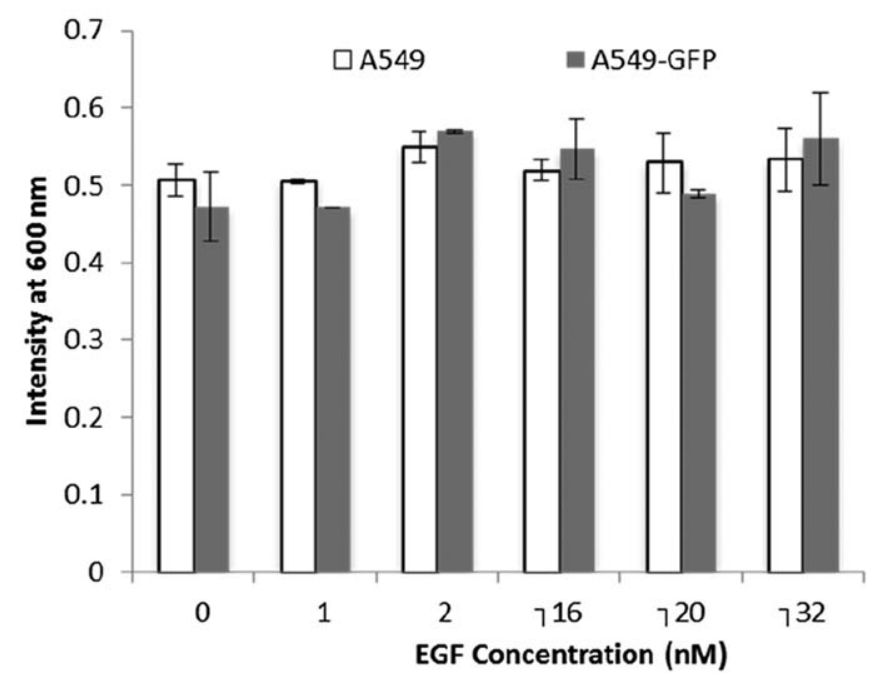

FIGURE 2 Absorbance intensity measured at $600 \mathrm{~nm}$ for A549 and A549-GFP stimulated with different concentrations of EGF. a-1-Absorbance intensity 8 hours after the first EGF stimulus and a-2-Absorbance intensity 8 hours of the second EGF stimulus 

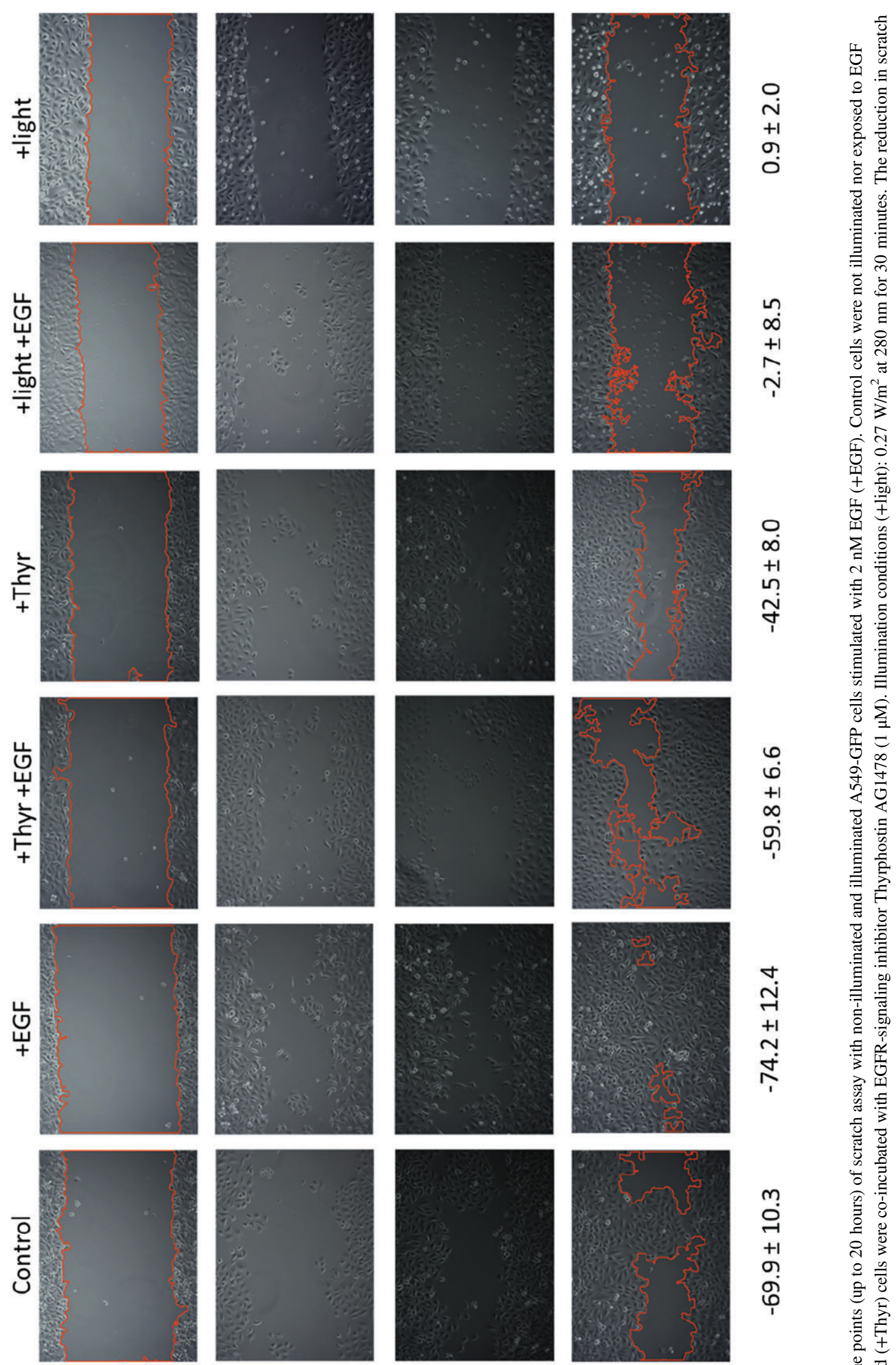

ธ

함
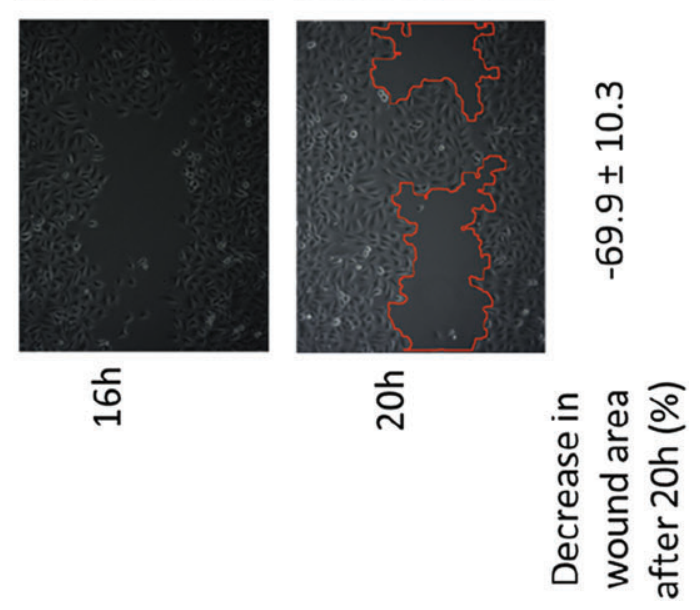

荇 ถู

装.

甹

$\sum_{1}$

政

ह

ర్ల

离节兽

包

原

守寺

选

预

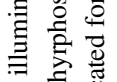

吾苛

昰 :

ั่

กิ

ソ

ホ 吾正

(⿹气口

氜

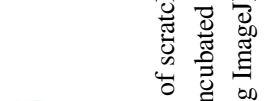

m

+1 ते

ต)

ดु है छ

参莹壭

咅总芯

可..

苛总焉

+ 됭 
(A)
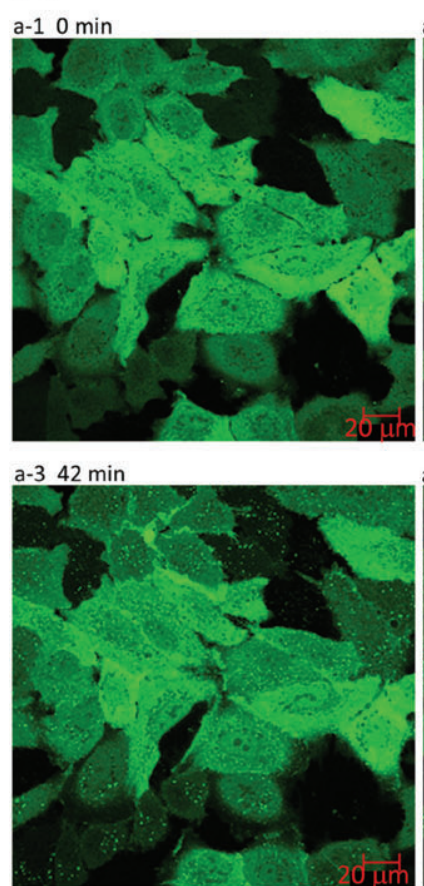
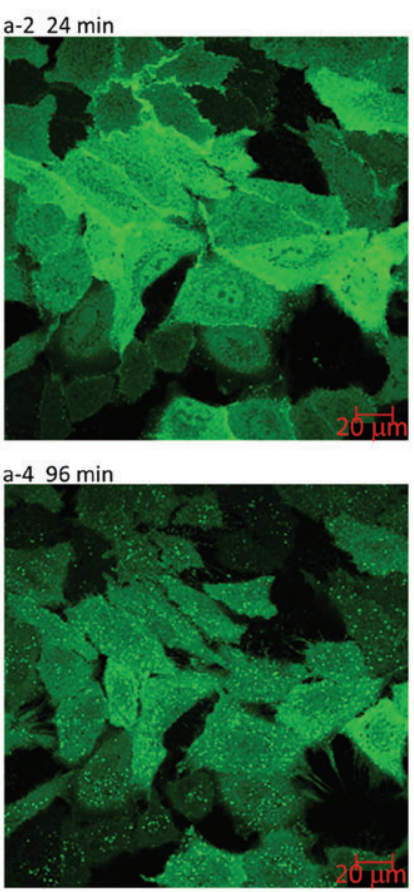

(B)

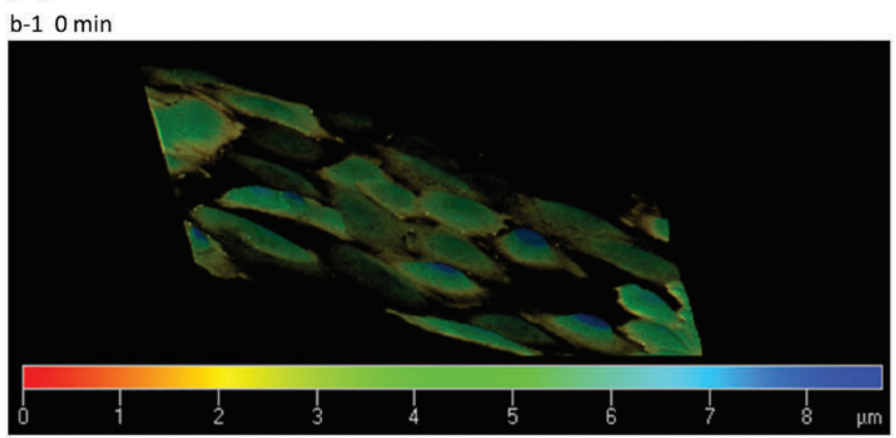

b-2 $102 \mathrm{~min}$

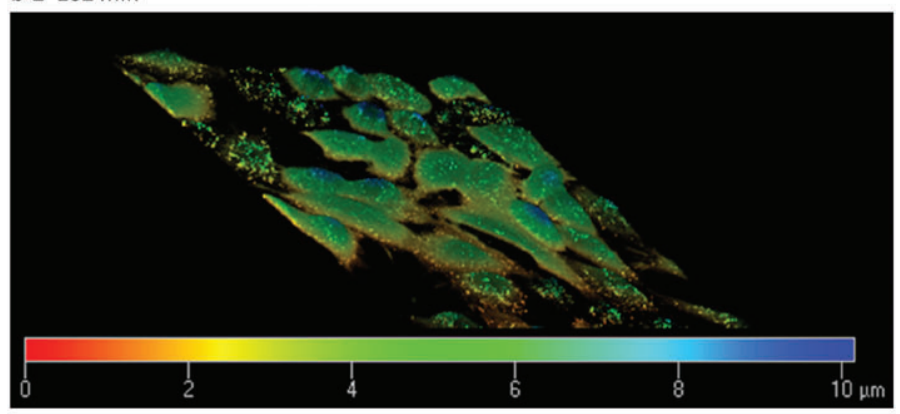

FIGURE 5 (A) CLSM images of 2 nM EGF stimulated cancer cells. a-1-Cell monolayer morphology and GFP fluorescence distribution before EGF addition; a-2-Morphology of cell monolayer and GFP fluorescence distribution after 24 minutes exposure to EGF. EGFR activation at the cell membrane level is observed; a-3-Morphology of cell monolayer and GFP fluorescence distribution after 42 minutes exposure to EGF. EGFR internalization if observed; a-4-Morphology of cell monolayer and GFP fluorescence distribution after 96 minutes exposure to EGF. EGFR internalization and cellular dissociation are observed. See also Movie S1_Fig5A. (B)_-3D reconstructed image of the cancer cells prior to EGF stimulation (panel b-1) and 3D reconstructed image of the cancer cells after 102 minutes exposure to EGF stimulation (panel b-2) showing EGF/EGFR internalization

that either maintaining EGF for 24 hours or renewing it every 8 hours to ensure its bioavailability in the medium leads to similar results prior to light treatments. As EGFR only remains active for less than 2 hours after stimulation of the cells [23] and DNA synthesis requires more than 8 hours of exposure to EGF, therefore, as described by others [23], renewal of EGF in the medium every 8 hours should stimulate cell proliferation. Therefore, cell proliferation was monitored up to 16 hours after the light pretreatment (before and after the renewal of EGF in the medium) as it would more reliably indicate the effects during the cell cycle of A549-EGFR biosensor cells and drastic differences further on would not be expectable. The illumination of the cancer cells challenged with $2 \mathrm{nM}$ EGF does not change their proliferation profile 8 hours after either the first or the second stimulus of EGF. We conclude that there are no statistically significant differences $(P>.05)$ concerning the proliferation of A549-GFP cells in the presence or absence of illumination.

In order to evaluate, in a functional assay, if cell mobility is altered when EGF-stimulated cells are irradiated, the scratch test was performed (Figure 4). The sequential images document that, in the presence of $2 \mathrm{nM}$ EGF (+EGF; $74.2 \% \pm 12.4 \%$ reduction of scratch area between 0 and 20 hours), non-illuminated A549-GFP cells more rapidly fill the scratch compared to nonexposed cells (Control; 69.9\% \pm $10.3 \%$ reduction of scratch area). Thyrphostin AG1478
(Thyr), at the concentration previously shown to inhibit EGFR signaling activation in A549 cells, effectively impairs cell migration, with (+EGF + Thyr; $59.8 \% \pm 6.6 \%$ reduction of scratch area) or without EGF (+Thyr; $42.5 \% \pm 8.0 \%$ reduction of scratch area) present. Illumination prior to addition of EGF (+light+EGF; reduction of scratch area in $2.7 \%$ $\pm 8.5 \%$ between 0 and 20 hours) has a striking inhibitory effect and clearly limits cell movement to fill the scratch. Light treatment alone (reduction of $0.9 \% \pm 2.0 \%$ of wound area) seems to affect unstimulated cells. CLSM data show that, prior to EGF addition, the cells are in a cohesive monolayer (Figure 5A, panel a-1). After 24 minutes of exposure to EGF, the activation of EGFR on the cell membrane is confirmed by bright green fluorescence observed at the cell membrane (Figure 5, panel a-2). At this stage, EGFR is predominantly located at cell-cell junctions. After 42 minutes, the formation of filopodia is clear as well as the internalization of the activated (phosphorylated) EGFR due to the presence of multiple green granules in the cytoplasm (Figure 5, panel a-3). Disintegration of the cell monolayer, with significant morphological changes and well-formed filopodia is observed 96 minutes after EGF addition (Figure 5, panel a-4 and F; Movie S1_Fig5A). In Figure 5B, panel b-1, no activation or internalization of EGFR was observed (time zero). However, 102 minutes after EGF addition, the internalization of the complex EGF/EGFR is clear (Figure 5B, panel b2). The presence of EGF results into 2 distinct phenomena: 
(A)

\section{a-1 0 min}

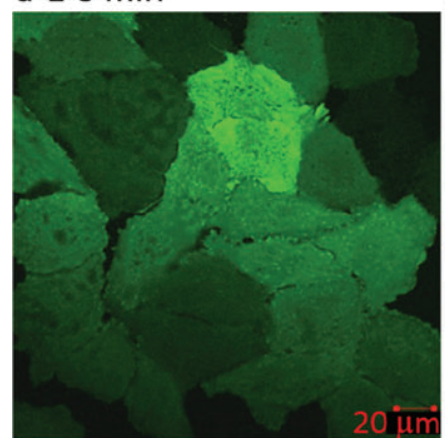

a-5 0 min

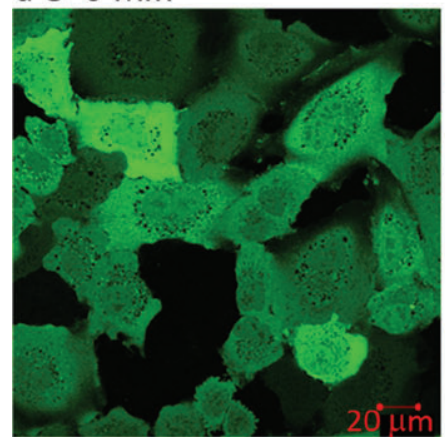

(B)

\section{b-1 $10 \mathrm{~min}$}

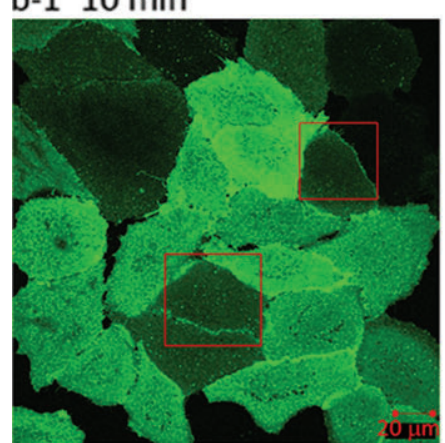

a-2 $10 \mathrm{~min}$

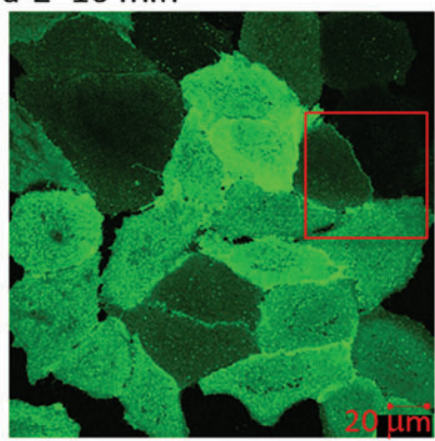

a-6 $10 \mathrm{~min}$

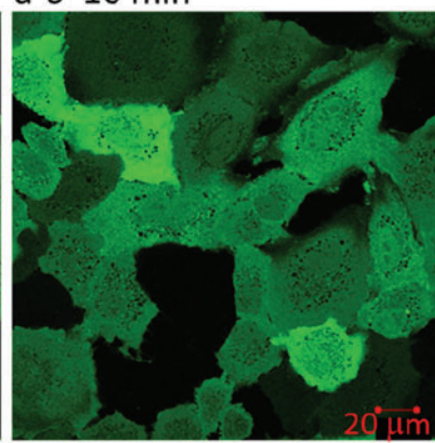

a-3 $40 \mathrm{~min}$

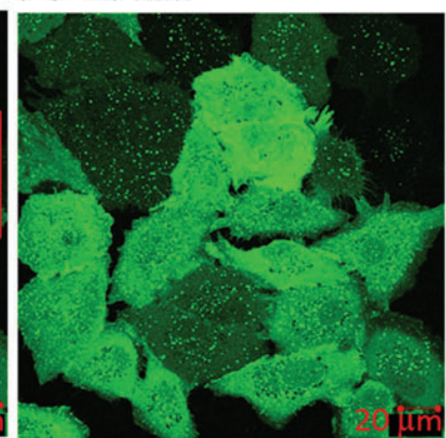

a-7 $40 \mathrm{~min}$

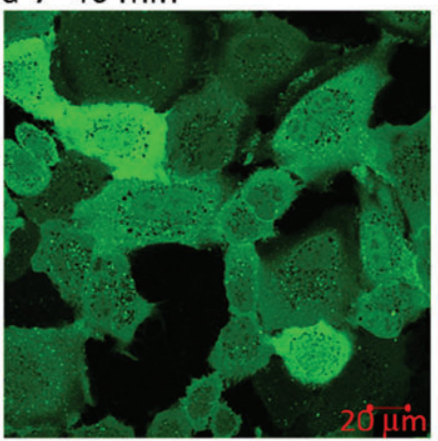

(C) b-2 $60 \mathrm{~min}$

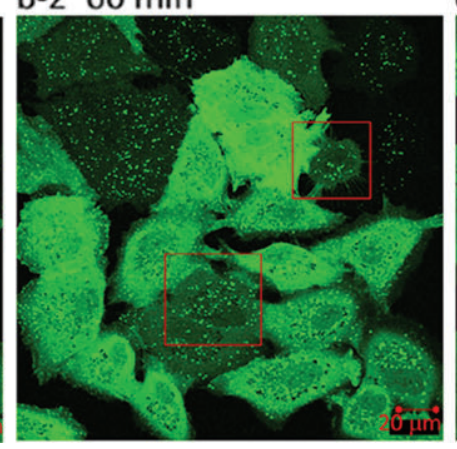

\section{c-1 $10 \mathrm{~min}$}

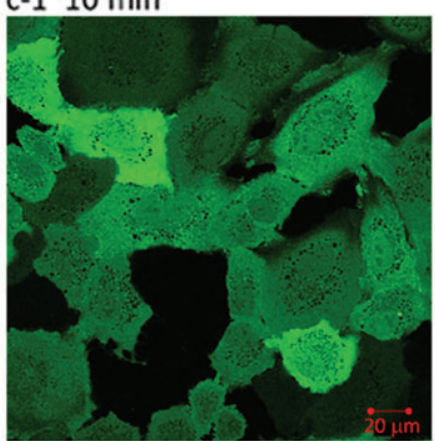

a-4 $60 \mathrm{~min}$

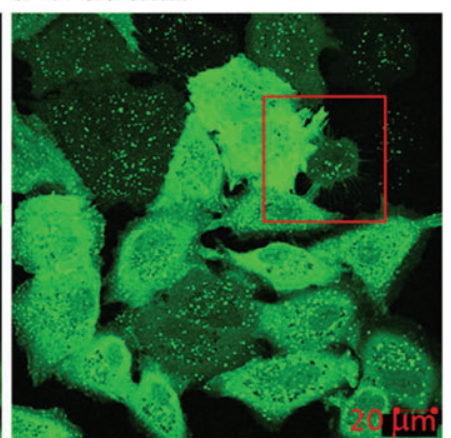

a-8 $60 \mathrm{~min}$

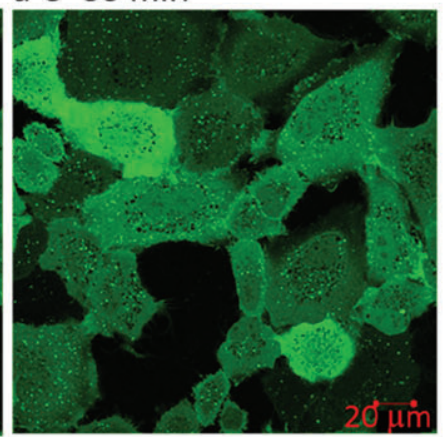

FIGURE 6 (A) CLSM images of cancer cells. a-1-Cell monolayer morphology and GFP fluorescence distribution before EGF addition (no UV illumination); a-2 to a-4 - Morphology of cell monolayer and GFP fluorescence distribution after 10, 40 and 60 minutes exposure to EGF, respectively (no UV illumination); a-5 to a8-Morphology of cell monolayer and GFP fluorescence distribution after 30 minutes of illumination with an irradiance of $0.09 \mathrm{~W} / \mathrm{m}^{2}$ before and after exposure to EGF for 10, 40 and 60 minutes, respectively. See also Movie S2_Fig6A_a5-a8 and Movie S3_Fig6A_a1-a4.

(B) Zoom into panel a-2 and a-4 of A, showing EGF-induced EGFR activation at the cellular membrane level and filopodia formation of the cancer cells after 10 minutes (b-1) and 60 minutes (b-2) of exposure to EGF. (C) Zoom into panel a- 6 and a-8 of A, showing the cell morphology and GFP fluorescence emission distribution after 30 minutes of illumination with an irradiance of $0.09 \mathrm{~W} / \mathrm{m}^{2}$ and after exposure to EGF for 10 minutes (c-1) and 60 minutes (c-2)

activation of EGFR at the membrane level and loss of the cohesiveness of the cell monolayer with consequent filopodia formation.

\subsection{1 $0.09 \mathrm{~W} / \mathrm{m}^{2}$ illumination series}

A monolayer of A549-GFP cells was illuminated at $280 \mathrm{~nm}$ with an irradiance of $0.09 \mathrm{~W} / \mathrm{m}^{2}$ for 30 and 15 minutes (Figures 6A, panels a-5-a-8 and Figure 7, respectively; see Movie S2_Fig6A_A5-A8). Subsequently, the cell monolayer was stimulated with $2 \mathrm{nM}$ EGF. As a control, A549-GFP cells were stimulated with 2 nM EGF in the absence of light (Figure 6A, panels a-1 to a-4-A4; see Movie S3_Fig6A_A1-A4). EGF addition to nonilluminated cells led to EGFR activation visible at the cell membrane of these biosensor cells (Figure 6A panel a-2). Morphological changes and filopodia formation were observed (Figure 6B panel b-2). Filopodia formation 60 minutes after irradiation and subsequent incubation with EGF (Figure 6A, panels a-8) was quantified and compared to the non-illuminated control (Figure 6A, panels a-4) 

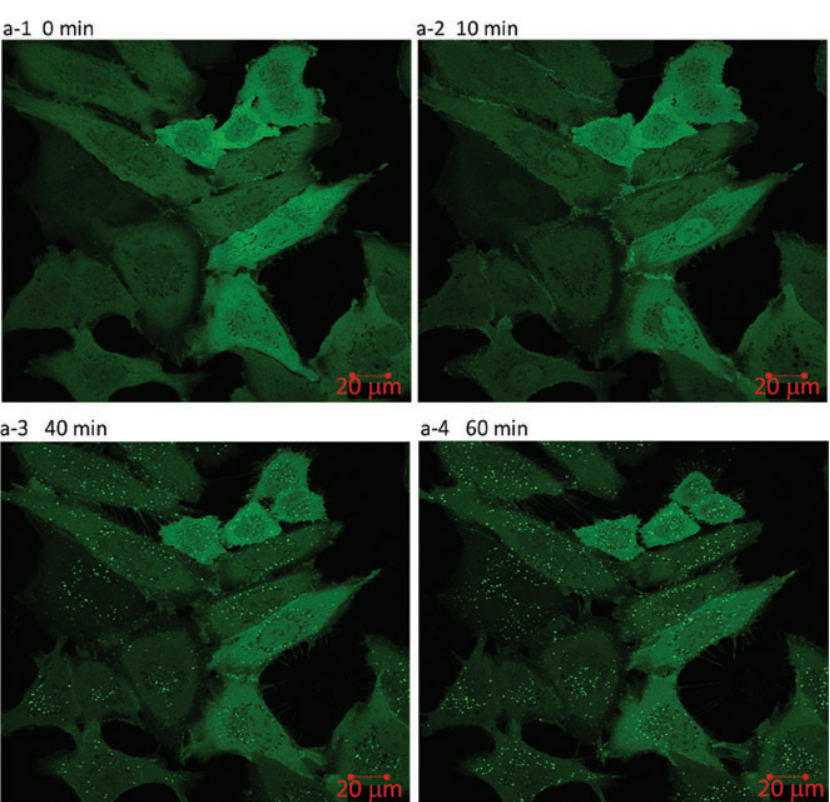

FIGURE 7 Morphology of cell monolayer and GFP fluorescence distribution after 15 minutes of $280 \mathrm{~nm}$ of illumination with an irradiance of $0.09 \mathrm{~W} / \mathrm{m}^{2}$. a-1 Before EGF addition; a-2, a-3, a-4 10, 40 and 60 minutes after EGF addition, respectively. See also Movie S4_Fig7

(Figure S2). Illumination of the cells prior to EGF addition (Figure 6A, panels a-5 to a-8) prevented or reduced EGFR activation and no significant morphology changes were noted. Formation of filopodia was not observed (Figure 6A, panels a-5 to a-8 and Figure 6C).

When the cell monolayer was illuminated at the same irradiance level $\left(0.09 \mathrm{~W} / \mathrm{m}^{2}\right)$ but for a shorter period of time (15 minutes; see Figure 7; Movie S4_Fig7), the decrease of EGFR activation is less pronounced when compared to the results obtained with 30 minutes of irradiation (Figure 6A).

\subsection{2 $0.27 \mathrm{~W} / \mathrm{m}^{2}$ illumination series}

Cancer epithelial cells were illuminated with $280 \mathrm{~nm}$ light at an irradiance of $0.27 \mathrm{~W} / \mathrm{m}^{2}$ for 15 minutes (Figure 8; Movie S5_Fig8_A-C and Movie S6_Fig8_D-F). For the nonilluminated cells, the addition of $2 \mathrm{nM}$ EGF led to brighter cell junctions, indicating activation of EGFR (Figure 8 panels a-1 to a-3), while no significant changes are observed if the cells have been illuminated for 15 minutes before EGF addition (Figure 8 panels a-4 to a-6). This fact confirms that illumination prior to stimulation with EGF prevents EGFR activation. Similar results were observed when these cells were illuminated for 30 minutes.

\subsection{3 $1.18 \mathrm{~W} / \mathrm{m}^{2}$ illumination series}

The cancer cells were then exposed to a higher irradiation level, $1.18 \mathrm{~W} / \mathrm{m}^{2}$, for 15 and 45 minutes. The new irradiation level is still lower than the maximum solar out of $1.75 \mathrm{~W} / \mathrm{m}^{2}$ at $39^{\circ} \mathrm{N}$ in summer $(<313 \mathrm{~nm})$ [15].

As it can be seen in Figure 9, the irradiation of the cells prior to their stimulation with 2 nM EGF (Figure 9 a- 2 and a-3) results in significant changes in the fluorescence pattern observed in comparison to non-irradiated EGF-stimulated cells (Figure 9 a-1), during imaging for a period of 102 minutes.

In the absence of light (Figure 9 a-1), EGF leads to significant internalization of the dimerized activated receptor, visible as fluorescent granules, altered cell morphology and reduced cell-cell contact, as expected. However, as observed in Figure 9 a-2, when the cells were pre-exposed to $280 \mathrm{~nm}$ light for 15 minutes, EGF fails to induce such striking formation of green fluorescent granules, and a more diffuse pattern, typical of nonactivated cells, is visible. The irradiation not only decreases EGFR activation, a-1 $0 \mathrm{~min}$

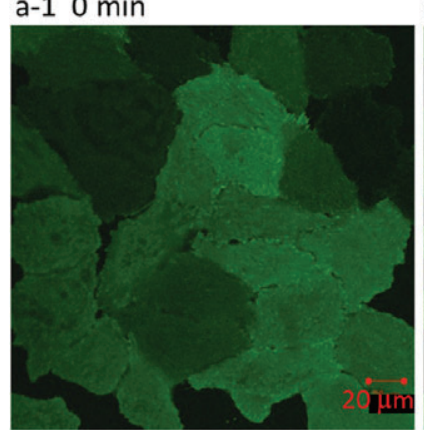

a-4 0 min

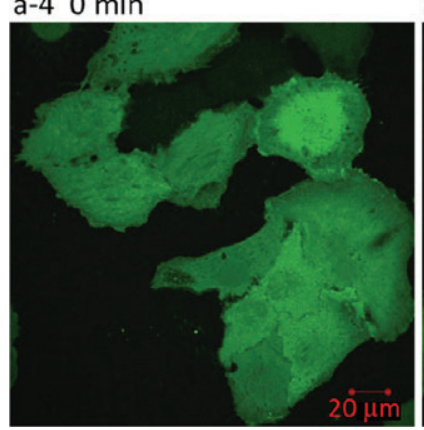

a-2 $12 \mathrm{~min}$
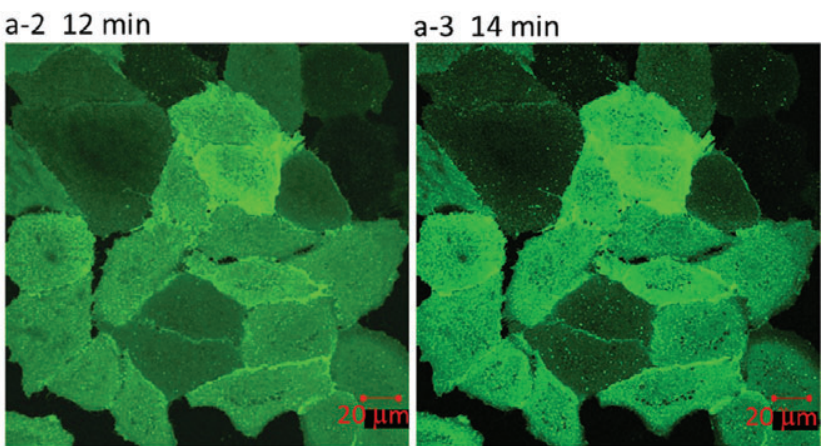

a-5 $12 \mathrm{~min}$

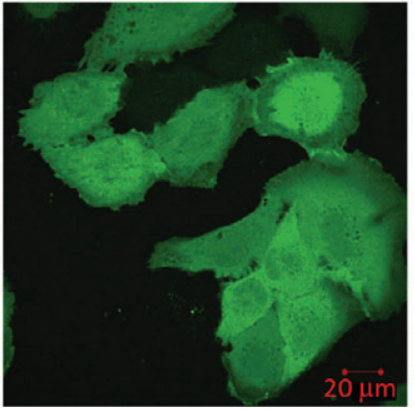

a-6 $14 \mathrm{~min}$

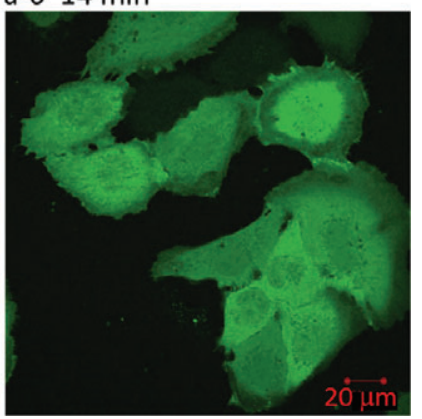

FIGURE 8 CLSM images of cancer cells showing morphology of the cell monolayer and GFP fluorescence distribution in nonilluminated (panels a-1, a-2, a-3) and illuminated cells (panels a-4, a-5, a-6, irradiance of $0.27 \mathrm{~W} / \mathrm{m}^{2}$ during 15 minutes), prior to and after EGF stimulation. Non-illuminated cells: panel a-1 - time of EGF addition, intact cell-cell junctions can be observed. Panels a-2, a3-Activation of EGFR localized at the cell membrane observed after 12 (a-5) and 14 minutes (a-6) exposure to EGF. Illuminated cells: EGFR activation is not observed at the cell membrane after 12 and 14 minutes exposure to EGF. See also Movie S5_Fig8_A-C and Movie S6_Fig8_D-F 
but also reduces cell-cell contact disaggregation (Figure 9 a-2). This observation was even more evident when the cells were exposed to $280 \mathrm{~nm}$ light for 45 minutes (Figure 9 a-3).

The images shown represent more than 3 datasets for each experimental condition used. Due to the large number of images obtained, not all images were presented.

\section{4 | DISCUSSION}

It is estimated that $33 \%$ to $50 \%$ of human carcinomas present an aberrant regulation of EGFR expression [8, 24-26]. One strategy to reduce the invasiveness of cancer cells is to block

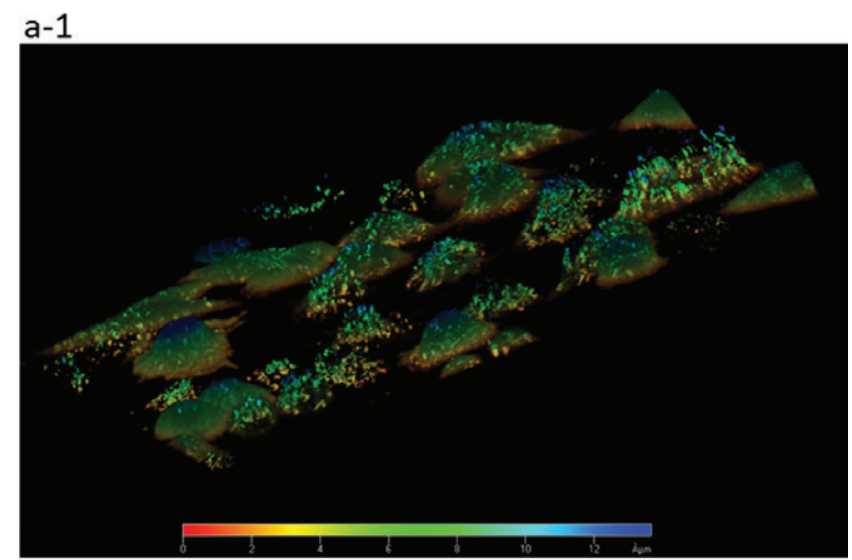

$\mathrm{a}-2$

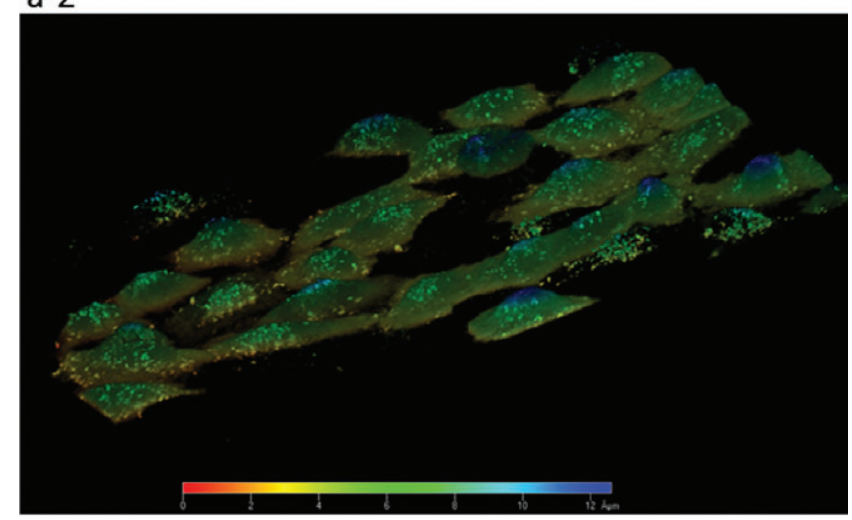

a-3

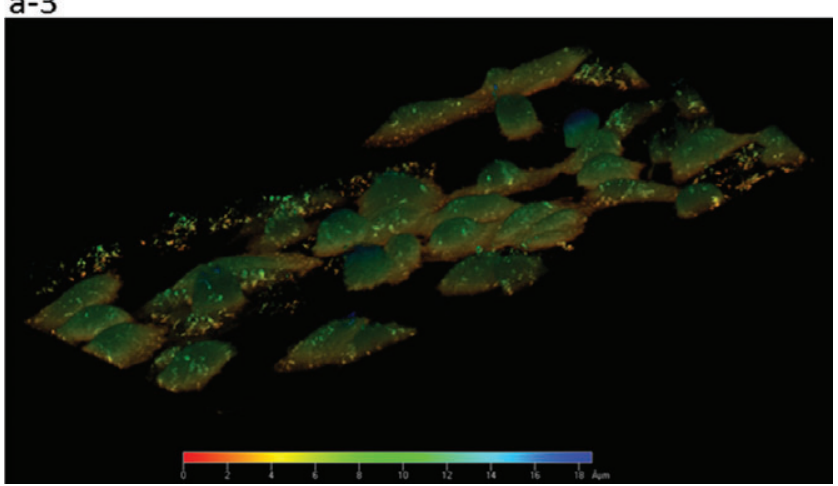

FIGURE 93 D reconstructed image of the cancer cells after 2 nM EGF stimulation for a period of 120 minutes. a-1 - In the absence of light; a-2, a3 -illuminated with an irradiance of $1.18 \mathrm{w} / \mathrm{m}^{2}$ for 15 and 45 minutes, respectively or halt the activation of EGFR using, for example, antibodies or tyrosine kinase inhibitors $[6,9,12,13]$. It is known that the structure of EGFR can be altered and rendered inactive by $280 \mathrm{~nm}$ light [16]. The present study confirmed the ability of $280 \mathrm{~nm}$ light to prevent EGF-EGFR activation and disclosed for the first time its inhibitory effect on migration of human lung carcinoma cells at irradiance values up to 20 times weaker than the UVB solar output and for short periods of time (15-45 minutes). The new findings may be used to design treatment approaches aimed at blocking metastasis formation using low level $280 \mathrm{~nm}$ light.

UV exposure is generally believed to cause skin cancer. This belief is only true for particular UV wavelengths and not for the whole UV range [27]. In fact, some UV wavelengths have therapeutic benefits: UVB $(280-315 \mathrm{~nm})$ light has been successfully used in the treatment of several skin diseases like psoriasis [28]. The most important contributor for vitamin D production is UVB light [28, 29]. Sunlight exposure has also been associated with improved cancer survival rates [30], as well as preventing colon, prostate and breast cancer [31, 32]. The International Electrotechnical Commission (2009) recommends that the maximum annual exposure should not exceed an erythemal-weighted dose of $0.3 \mathrm{~W} / \mathrm{m}^{2}$ [33]. In this study, the doses used were 0.09 and $0.27 \mathrm{~W} / \mathrm{m}^{2}$ for 30 minutes, which correspond to $30 \%$ and $90 \%$, respectively, of the recommended value to avoid erythema.

The presence of different concentrations of EGF is known not to have a drastic effect on the cell's proliferation rate [23]. This is corroborated by our results, which consistently show a similar behavior in parental A549 cells and in the reporter cell line A549-GFP, and further validate the use of the latter (Figures 1 and 2). In Figure 3, it is possible to observe that the irradiation of cancer cells with $280 \mathrm{~nm}$ light, with an irradiance of $0.27 \mathrm{~W} / \mathrm{m}^{2}$ for a period of 30 minutes, does not alter the proliferation rate of the cells even when stimulated with EGF. However, the same illumination conditions reduce cellular migration upon EGF stimulation, even more than with a specific pharmacological EGFR-signaling inhibitor (Thyrphostin AG1478), as clearly shown in Figure 4. Being an EGFR specific inhibitor, Thyrphostin may interfere with EGFR-dependent pathways which involve cell proliferation although this specific effect has not been described yet.

In non-illuminated cells, EGF induces visible EGFR activation followed by receptor internalization which is in agreement with literature [21, 22, 34]. The work by Silva et al. confirmed that such enhancement of green fluorescence was due to the formation of the EGFR-EGF complex, as the presence of an antibody against EGFR has prevented EGF binding to EGFR and no enhancement of green fluorescence at the cell membrane level and complex internalization were observed [35]. 
Disintegration of the cancer cell monolayer is associated with filopodia formation (Figure 5A, panel a-4) and this observation is positively correlated with the epithelialmesenchymal transition process [32, 36, 37]. Activation and internalization of EGFR are known to lead to the internalization of E-cadherin, a key adhesion protein [38], resulting in the loss of cell junctions adherence and, consequently, tissue disaggregation [39]. The present data are positively correlated with that proposed mechanism. The invasive phenotype of the cancer cells observed upon activation by EGF is supported by the formation of filopodia, visible in Figure 5A (panel a-4) and Figure 6B (panel b-2).

The investigation of the effect of $280 \mathrm{~nm}$ light on preventing the activation and migration of lung carcinoma cells overexpressing EGFR has been carried out using different irradiance values: $0.09,0.27$ and $1.18 \mathrm{~W} / \mathrm{m}^{2}$. The 2 lower levels fall below the total irradiance of sunlight in the UVB region $(280-315 \mathrm{~nm})$ reported to be $\sim 0.78 \mathrm{~W} / \mathrm{m}^{2}$ [40], and $1.75 \mathrm{~W} / \mathrm{m}^{2}$ at $39^{\circ} \mathrm{N}$ in summer and $0.4 \mathrm{~W} / \mathrm{m}^{2}$ in December $(<313 \mathrm{~nm})$ [15]. The highest irradiance used in this study $\left(1.18 \mathrm{~W} / \mathrm{m}^{2}\right)$ is intermediate between summer and winter sunlight UVB irradiance. CLSM showed that $280 \mathrm{~nm}$ light inhibited EGF-mediated activation of EGFR and inhibited cellular migration (Figures 6A and 7). It has been reported that $280 \mathrm{~nm}$ irradiation leads to the arrest of EGFRdependent key signaling pathways [14] and leads to conformational changes in the EGF binding site in EGFR, impairing the correct interaction with ligands [16]. If $280 \mathrm{~nm}$ excitation of GFP at the irradiance levels used had affected the structure of GFP, due to photochemistry, it would be expected that the fluorescence of the Ser-Tyr-Gly chromophore in GFP would have been compromised, as Tyr absorbs at $280 \mathrm{~nm}$. Therefore, we ascertain that $280 \mathrm{~nm}$ excitation of GPF under the illumination conditions used had no effect on the green fluorescence emission intensity distribution of the Ser-Tyr-Gly chromophore in GFP.

Illumination time was found to be a very important factor: 30 minutes of $280 \mathrm{~nm}$ irradiation at $0.09 \mathrm{~W} / \mathrm{m}^{2}$ was more efficient than 15 minutes illumination in preventing EGFR activation, filopodia formation and cellular migration (Figure 6A [panels a5 to a-8] and Figure 7, respectively). This is in agreement with previous results [14] reporting that $280 \mathrm{~nm}$ illumination of cancer cells overexpressing EGFR (A431, human epidermoid carcinoma cells and Cal39, derived from human vulva squamous cell carcinoma cells) blocked EGFR signaling above a particular illumination time (30 minutes) at a particular irradiance value $\left(0.35 \mathrm{~W} / \mathrm{m}^{2}\right)$. In the present study, the efficiency of $280 \mathrm{~nm}$ illumination in preventing EGFR activation, filopodia formation and cellular migration was tested at an irradiance level $\left(0.27 \mathrm{~W} / \mathrm{m}^{2}\right)$ close to what was previously reported $\left(0.35 \mathrm{~W} / \mathrm{m}^{2}[14]\right)$ and 1 order of magnitude lower $\left(0.09 \mathrm{~W} / \mathrm{m}^{2}\right)$. Both irradiance levels successfully prevented EGF-induced cell migration. As demonstrated in Figure 9, an increase of the irradiation level and exposure time delays or even halts EGFR activation, internalization, filopodia formation and cell migration. The blocking effect over EGFR signaling by UV light treatment is very marked with 30 minutes of irradiation with 0.09 and $0.27 \mathrm{~W} / \mathrm{m}^{2}$ light before stimulation with EGF, while treatment with only 15 minutes of $1.18 \mathrm{~W} / \mathrm{m}^{2}$ light is sufficient to cause an inhibition of EGFR activation. Bunsen-Roscoe reciprocity law, that is, the extent of photochemical effects is determined by cumulative irradiance, is particularly evident when comparing results obtained with 15 minutes treatment with the lowest and highest irradiances $(0.09$ and $1.18 \mathrm{~W} / \mathrm{m}^{2}$, respectively) (Figure S2). With $0.09 \mathrm{~W} / \mathrm{m}^{2}$, the achieved blocking effect of EGFR signaling starts fading already after 8 minutes, as signs of activation become visible. The highest irradiance tested can block EGFmediated activation up to 22 minutes. The intermediate irradiance tested does lead to concordant results although not as clearly distinguishable, as cellular mechanisms can and certainly do mask this effect. At 16 minutes of exposure to EGF, cells pretreated with $0.27 \mathrm{~W} / \mathrm{m}^{2}$ light suggest some cell activation, as indicated by the arrows.

The results presented in this paper are in line with the report that $280 \mathrm{~nm}$ light induces conformational changes in EGFR, preventing its activation [17]. This is also corroborated by Yamauchi et al. [41] and Kawaguchi et al. [42] which showed that when pancreatic cells are irradiated at $254 \mathrm{~nm}$, there is a downregulation of EGFR expression. Both 254 and $280 \mathrm{~nm}$ light lead to disruption of disulfide bridges in proteins, such as EGFR, most likely compromising their structure and, therefore, their function [43].

The new photonic strategy aims at disrupting the structure and function of EGFR and therefore it is targeted to cells overexpressing EGFR, a receptor that is expressed or highly expressed in a variety of common solid tumors and associated with poor prognosis. EGFR is the target of many chemotherapeutical approaches. High expression of EGFR is a hallmark of many types of tumors, such as head and neck, non-small cell lung cancer (NSCLC), breast, prostate, ovarian, glioblastoma, esophageal or skin cancer [44]. In most cases, it is associated with poor prognosis and several EGFR signaling targeting therapies (eg, erlotinib and cetuximab) have been developed and applied in the clinic. The possibility of preventing EGF-mediated activation of EGFR with low dose UV light that could be delivered locally using portable LED lights, alone or in synergistic combination with the already used chemotherapies, could be helpful almost immediately for battling accessible tumors such as skin lesions, ovarian or esophageal cancers among others. In the long run, the development of other light delivery systems and the optimization of irradiation time/intensity could greatly widen the range of applications. We propose an alternative photonic strategy to halt EGFR signaling pathway, at a specific wavelength that has the lowest probability in the 
whole UVB spectrum to induce skin cancer, erythema or even keratitis (inflammation of the cornea) [27].

Since light is used in this putative new therapy, we can confine the illumination onto the cancer tissue, minimizing irradiation of healthy cells. The irradiance levels used are nevertheless below damaging thresholds for normal cells since the energy per unit area applied in our studies is several orders of magnitude below the level known to cause DNA photoionization [45] and lead to the formation of cyclobutane pyrimidine dimers (CPDs) which is the principal lesion responsible for most DNA damage-dependent biological effects of sunlight [46, 47]. The peak of this action spectrum is near $300 \mathrm{~nm}$ and decreases rapidly at both longer and shorter wavelengths [48]. The energy per unit area used reporting $280 \mathrm{~nm}$ induced CPD formation [49] are up to $\times 100$ larger than the energy levels per unit area used in this study. Nonetheless, to confirm the safety of the light treatment protocols, we have carried out in parallel zebra fish embryogenesis studies designed to evaluate possible effects of 8 or $24 \mathrm{hpf}$ embryo irradiation with 5,15 or 30 minutes of $280 \mathrm{~nm} \mathrm{UV} \mathrm{light} \mathrm{(at} \mathrm{the} \mathrm{reported} \mathrm{irradiance} \mathrm{of} 0.27 \mathrm{~W} /$ m2) (unpublished data). No cumulative mortality was observed and only marginal effects were detected on heart rate and hatching among 8 different development parameters assessed.

The results show that low dose $280 \mathrm{~nm}$ light has a potential therapeutic effect in cancer treatment. The proposed new photonic therapy may be used alone or combined with other cancer therapies. It has advantages over other photonic cancer therapies, such as photodynamic therapy, since there is no need to use a photosensitizer.

\section{ACKNOWLEDGMENTS}

The authors acknowledge funding from the Portuguese Foundation for Science and Technology (FCT) for the scholarships SFRH/BPD/111291/2015 (CMB) and SFRH/BSAB/ 127924/2016 (ACG). This work was supported by the strategic programme UID/BIA/04050/2013 (POCI-01-0145-FEDER007569) funded by national funds through the FCT I.P. and by the ERDF through the COMPETE2020-Programa Operacional Competitividade e Internacionalização (POCI). This work was also supported by FCT under the scope of the strategic funding of UID/BIO/04469/2013 unit and COMPETE 2020 (POCI-01-0145-FEDER-006684) and the Project RECI/BBBEBI/0179/2012 (FCOMP-01-0124-FEDER-027462).

\section{AUTHOR BIOGRAPHIES}

Please see Supporting Information online.

\section{ORCID}

Cláudia M. Botelho (D) http://orcid.org/0000-0001-8221-419X Odete Gonçalves (D) http://orcid.org/0000-0002-4614-6158
Viruthachalam Thiagarajan (DD http://orcid.org/0000-0003-4197-2255

Henrik Vorum (DD http://orcid.org/0000-0002-7600-0731

Andreia C. Gomes (D) http://orcid.org/0000-0002-0567-064X

Maria Teresa Neves-Petersen (D) http://orcid.org/0000-0003-3178-3709

\section{REFERENCES}

[1] K. Oda, Y. Matsuoka, A. Funahashi, H. A. Kitano, Mol. Syst. Biol. 2005, 1, 2005.0010 .

[2] G. Carpenter, Annu. Rev. Biochem. 1987, 56, 881.

[3] G. Carpenter, S. Cohen, J. Biol. Chem. 1990, 265, 7709.

[4] A. Ullrichand, J. Schlessinger, Cell 1990, 61, 203.

[5] T. W. Gadellaand, T. M. Jovin, J. Cell Biol. 1995, 129, 1543.

[6] D. Irmer, J. O. Funkand, A. Blaukat, Oncogene 2007, 26, 5693.

[7] M. J. Wieduwiltand, M. M. Moasser, Cell. Mol. Life Sci. 2008, 65, 1566.

[8] J. Mendelsohn, a J. Baselga, Oncogene 2000, 19, 6550.

[9] M. Scaltriti, J. Baselga, Clin. Cancer Res. 2006, 12, 5268.

[10] W. Zhang, T. H. Liu, Cell Res. 2002, 12, 9.

[11] H. Zhang, A. Berezov, Q. Wang, G. Zhang, J. Drebin, R. Murali, M. Greene, J. Clin. Invest. 2007, 117, 2051.

[12] M. E. Noble, J. A. Endicott, L. N. Johnson, Science 2004, 303, 1800.

[13] S. Oliveira, P. M. P. van Bergen en Henegouwen, G. Storm, R. M. Schiffelers, Expert Opin. Biol. Ther. 2006, 6, 605.

[14] B. B. Olsen, M. T. Neves-Petersen, S. Klitgaard, O. G. Issinger, S. B. Petersen, Int. J. Oncol. 2007, 30, 181.

[15] A. Pirie, Biochem. J. 1971, 125, 203.

[16] M. Correia, V. Thiagarajan, I. Coutinho, G. P. Gajula, S. B. Petersen, M. T. Neves-Petersen, PLoS One 2014, 9, e111617.

[17] I. Coutinho, M. Correia, V. Thiagarajan, G. P. Gajula, S. B. Petersen, M. T. Neves-Petersen, Photonic cancer therapy: modulating cellular metabolism with light, Proc. SPIE 8568, Optical Methods for Tumor Treatment and Detection: Mechanisms and Techniques in Photodynamic Therapy XXII, 2013, 856806, https://doi.org/10.1117/12.2004043.

[18] M. L. Jaramillo, M. Banville, C. Collins, B. Paul-Roc, L. Bourget, M. O'Connor-McCourt, Cancer Biol. Ther. 2008, 7, 557.

[19] A549 Cells GFP-EGFR । Sigma-Aldrich, http://www.sigmaaldrich.com/ catalog/product/sigma/cll1141 ?lang=pt\&region=PT (accessed: 22 March 2017).

[20] C. Antczak, A. Bermingham, P. Calder, D. Malkov, K. Song, J. Fetter, H. Djaballah, Assay Drug Dev. Technol. 2012, 10, 24.

[21] C. Antczak, J. P. Mahida, B. Bhinder, P. A. Calder, H. A. Djaballah, J. Biomol. Screen. 2012, 17, 885 .

[22] C. Antczak, H. A. Djaballah, Methods Mol. Biol. 2016, 1360, 97.

[23] S. Pennock, Z. X. Wang, Mol. Cell. Biol. 2003, 23, 5803.

[24] J. R. Woodburn, Pharmacol. Ther. 1999, 82, 241.

[25] Y. Yarden, M. X. Sliwkowski, Nat. Rev. Mol. Cell Biol. 2001, 2, 127.

[26] D. Polsky, C. Cordon-Cardo, Oncogene 2003, 22, 3087.

[27] Ultraviolet Radiation: OSH Answers, http://www.ccohs.ca/oshanswers/ phys_agents/ultravioletradiation.html. Accessed 25 October 2017

[28] A. Juzeniene, J. Moan, Dermatoendocrinology 2012, 4, 109.

[29] M. K. B. Bogh, Scand. J. Clin. Lab. Invest. Suppl. 2012, 243, 24.

[30] H. S. Lim, R. Roychoudhuri, J. Peto, G. Schwartz, P. Baade, H. Møller, Int. J. Cancer 2006, 119, 1530

[31] J. Reichrath, W. Tilgen and M. Friedrich, in: Vitamin D Analogs in Cancer Prevention and Therapy, Springer, Berlin, Heidelberg, 2003, 2003.

[32] J. P. Thiery, Nat. Rev. Cancer 2002, 2, 442.

[33] International Electrotechnical Commission, in: Household and Similar Electrical Appliances-Safety-Part 2-27: Particular Requirements for Appliances for Skin Exposure to Ultraviolet and Infrared Radiation, Report International Electrotechnical Commission, Geneva, Switzerland 2009.

[34] A. Sorkin, L. K. Goh, Exp. Cell Res. 2009, 315, 683.

[35] C. O. Silva, S. B. Petersen, C. P. Reis, P. Rijo, J. Molpeceres, A. S. Fernandes, O. Gonçalves, A. C. Gomes, I. Correia, H. Vorum, M. T. Neves-Petersen, PLoS One 2016, 11, e0165419.

[36] Y. Kang, J. Massagué, Cell 2004, 118, 277.

[37] M. Yilmaz, G. Christofori, Cancer Metastasis Rev. 2009, 28, 15.

[38] N. Pećina-Slaus, Cancer Cell Int. 2003, 3, 17.

[39] G. P. Solis, Y. Schrock, N. Hülsbusch, M. Wiechers, H. Plattner, C. A. Stuermer, Mol. Biol. Cell 2012, 23, 1812 . 
[40] ASTM Subcommittee G03.09 (2003) ASTM G173-03 Standard Tables for Reference Solar Spectral Irradiance Direct Normal and Hemispherical on $37^{\circ}$ Tilted Surface, Annual Book of ASTM Standards, 2003, Vol. 14.04, ASTM International, West Conshohocken, PA Open Access. http://www. oalib.com/references/11745669. (Accessed: 1st February 2016).

[41] T. Yamauchi, S. Adachi, I. Yasuda, M. Nakashima, J. Kawaguchi, Y. Nishii, T. Yoshioka, Y. Okano, Y. Hirosse, O. Kozawa, H. Moriwaki, Radiat. Res. 2011, 176, 565.

[42] J. Kawaguchi, S. Adachi, I. Yasuda, T. Yamauchi, T. Yoshioka, M. Itani, O. Kozawa, H. Moriwaki, Oncol. Rep. 2012, 27, 935.

[43] M. T. Neves-Petersen, S. Klitgaard, T. Pascher, E. Skovsen, T. Polivka, A. Yartsev, V. Sundström, S. B. Petersen, Biophys. J. 2009, 97, 211.

[44] C. Arteaga, Semin. Oncol. 2003, 30, 3.

[45] S. Marguet, D. Markovitsi, F. Talbot, J. Phys. Chem. B 2006, 110, 11037.

[46] E. C. Friedberg, G. C. Walker, W. Siede, R. D. Wood, R. A. Schultz, T. Ellenberger, DNA Repair and Mutagenesis, 2nd ed., ASM Press, Washington, DC, 2006, p. 2006.

[47] P. Slavíček, B. Winter, M. Faubel, S. E. Bradforth, P. Jungwirth, J. Am. Chem. Soc. 2009, 131, 6460.

[48] S. E. Freeman, H. Hacham, R. W. Gange, D. J. Maytum, J. C. Sutherland, Med. Sci. 1989, 86, 5605.

[49] A. Besaratinia, J. I. Yoon, C. Schroeder, S. E. Bradforth, M. Cockburn, G. P. Pfeifer, FASEB J. 2011, 25, 3079.

\section{SUPPORTING INFORMATION}

Additional supporting information may be found online in the Supporting Information section at the end of the article.

FIGURE S1 Proliferation of A549-GFP cells stimulated with 2 nM EGF, measured by Sulforhodamine B; after 8 and $24 \mathrm{~h}$ (A) and over a period of 4 days (B); the effect of serum starvation (on starvation vs $2 \mathrm{~h}$ starvation before EGF addition) and of renewal of EGF every $8 \mathrm{~h}$ in A549-GFP cell proliferation at $24 \mathrm{~h}(\mathrm{C})$

FIGURE S2 The images were divided in quadrants of 22144 pixcel $^{2}$ and average values of 9 quadrants per image were calculated

FIGURE S3 Blocking effect of EGFR signaling in Human A549-EGFR biossensor cell line with pretreatment of 15 min illumination is longer with higher irradiance level, suggesting Bunsen-Roscoe reciprocity law effect

Movie S1 Supporting Information

Movie S2 Supporting Information

Movie S3 Supporting Information

Movie S4 Supporting Information

Movie S5 Supporting Information

Movie S6 Supporting Information

How to cite this article: Botelho $\mathrm{CM}$, Gonçalves $\mathrm{O}$, Marques R, et al. Photonic modulation of epidermal growth factor receptor halts receptor activation and cancer cell migration. J. Biophotonics. 2018;11: e201700323. https://doi.org/10.1002/jbio.201700323 